\title{
Identification and Delineation of Lineament Zones in VGTM Region
}

\author{
Kirthi Chandra ${ }^{1}$, Deen Maqbool Ahmed ${ }^{2}$, Sai Sanath ${ }^{3}$ \\ Assistant Professor, Architecture Department, School of Planning and Architecture, Vijayawada, India ${ }^{1,3}$ \\ Assistant Professor, Planning Department, School of Planning and Architecture, Vijayawada, India ${ }^{2}$
}

\begin{abstract}
This article aims to identification and delineation the lineament in Vijayawada Guntur Tenali Mangalagiri (VGTM) Region. The total area of VGTM Region is 20130.50 sq.kms. It is assessed based on the data retrieved from Satellite Imagery, Survey of India and conventional methods. This area is under Seismic Zone-III and 26 minor lineament are been Identified by the Earthquake Engineering Research Centre (EERC), International Institute of Information Technology (IIIT), Hyderabad, India. This process involves the overlapping of different material and analysis where the lineaments exist which further leads to the demarcation of the area. This study is conducted by using gravity data, remotely sensed imagery and recent field studies. These lineaments are represented in the form of tree diagram, with linear or circular form of disturbance generated in the tectonic fractures in the earth bedrock. Furthermore, the use of these studies could be combined to focus on the lineament based on Vijayawada Guntur Tenali Mangalagiri (VGTM) region which could represent the geologically fractured area and eminently provides us with ground water potential. These studies could result in developing new dimension to understand and study the topography, drainage and vegetation patterns of earth geology for means of preserving the parcel of land and its natural resources in the form of different wetlands and ecological sensitive areas. The main barrier in the study is identifying the morphological pattern and vegetation which can be observed through satellite imageries and can be enhanced by using remote sensing spatial data. These findings can be used as a guidance for the understanding the potential of ground water availability, vegetation pattern, soil distribution along with many other environmental factors including thermal comfort zones, Heat Island Effect and ecologically sensitive areas.
\end{abstract}

Keywords: Lineament map, Geological pattern, Hydrology potential, Vijayawada Morphology

\section{INTRODUCTION}

Lineament, fracture and fault are the emerging areas of geology and hydrology which can triggers a vibrant character in soil and natural drainage patterns. "A lineament is a map able, simple or composite linear feature of a surface, whose parts are aligned in a rectilinear or slightly curvilinear relationship and which differs distinctly from the patterns of adjacent features and presumably reflects a subsurface phenomenon" . These lineaments are one of the geomorphologic aspects which have to be considered at the initial stage of master planning under the parameters of hydro geologic cycle.

Lineaments are the ruptures over or below the surface of the earth, are studied by geologist and hydrologist for the change in the soil and water drainage pattern. Now a day's these are popular among the environmentalists, ecologists, landscape architects and Urban planners who prefers to consider this as a part of geomorphology. It has the potential to conserve the ecosystem by the rich fertile lands and by filtering the water.

Vijayawada is the second largest city in Andhra Pradesh and is sensitive to earthquakes. It is located in the delta region of Krishna river. The top soil with its stratification levels and the seismic reading in the history reveals that the Vijayawada and the periphery areas fall under the Zone III as per IS 1893: 2002. This type of geological aspects enriches the quality of natural ecosystem by treating the soil and water quality.
"The actual ecological measurements can be considered by studying the lineaments and physiology of an unspoiled landscape".

\section{Study Area - Vijayawada Guntur Tenali MANGALAGIRI (VGTM)REGION:}

The VGTM region has been formed by combining the two coastal districts of Guntur and Krishna district from the state of Andhra Pradesh (Newly formed after 2014) with a total area of $20130.50 \mathrm{sq} . \mathrm{km}$ and coastline of $130 \mathrm{~km}$. The coastal districts are situated between $15^{\circ}, 18^{\prime \prime} \mathrm{N}$ \& $17^{\circ}, 10^{\prime} \mathrm{N}$ latitude and $81^{\circ} 33^{\prime} \mathrm{E}$ of longitude. The region is surrounded on eastern side by the Bay of Bengal and west Godavari District on the Western side by Prakasam and Mahaboobnagar districts, on the South and east part of Andhra Pradesh. The region has in its vicinity, 4 major metropolitans- namely Hyderabad, Chennai, Bangalore and Kolkata.

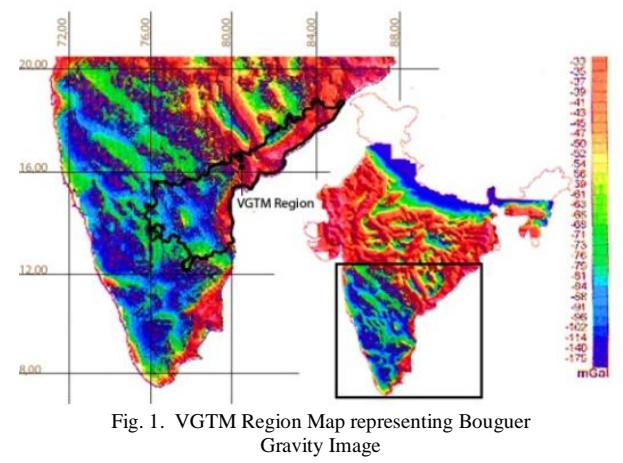




\section{A. Demography}

The total population of the region as per census 2011 is 9405241 of which total male population is 4707896 and total female population is 4697315 . The region constitutes $19 \%$ in proportion to Andhra Pradesh population. The total urban population is $3514036(37 \%)$ and total rural population is $5904203(63 \%)$.

TABLE 1

DisTRICT WiSE DISTRIBUTION OF POPULATION (1991-2011)

\begin{tabular}{|c|c|c|c|c|c|}
\hline \multirow[t]{2}{*}{ District } & \multicolumn{3}{|c|}{$\begin{array}{c}\text { Total Population (in } \\
\text { lakhs) }\end{array}$} & \multirow{2}{*}{$\begin{array}{c}\text { Decadal } \\
\text { Growth } \\
\text { Rate } \\
1991-01\end{array}$} & \multirow{2}{*}{$\begin{array}{c}\text { Decadal } \\
\text { Growth } \\
\text { Rate } \\
2001-11\end{array}$} \\
\hline & 1991 & 2001 & 2011 & & \\
\hline Krishna & 36.90 & 41.88 & 45.17 & $13 \%$ & $8 \%$ \\
\hline Guntur & 41.06 & 44.65 & 48.87 & $9 \%$ & $9 \%$ \\
\hline
\end{tabular}

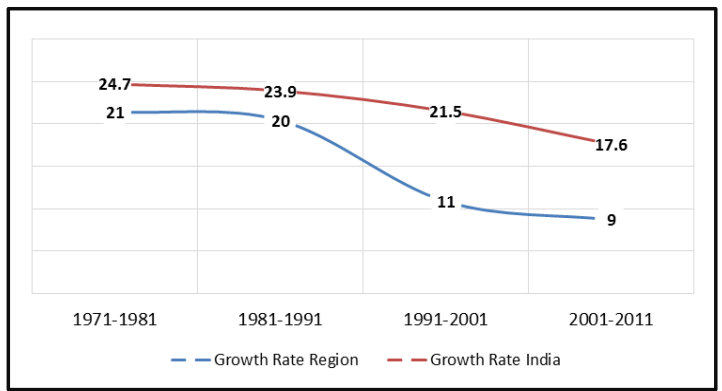

Fig 2: Population growth trends

Krishna shows comparatively less Decadal Growth Rate from 1991-01 to 2001-11, whereas Guntur has a stagnant Decadal Growth Rate.

\section{B. Historical Transition of Climate Conditions of VGTM Region:}

The region receives a normal rainfall of $851.00 \mathrm{~mm}$ $1034 \mathrm{~mm}$, of which $2 / 3 \mathrm{rd}$ is received through the south west monsoon. The climate is generally warm in summer and the heat is very severe in rentachintala, where the maximum temperature in the State is recorded. Tropical Climate conditions with extreme hot summer and cold winter prevail in this district. April - June are the months with high temperature specially in the month of May and it falls under the Semi-arid climatic zone. The Agro Climatic Zone of the area falls under the three major zones namely: Agro Ecological Sub Region (ICAR) Eastern Coastal plain, hot sub-humid to semi-arid eco region, Agro-Climatic Region (Planning Commission): East Coast plain and hill region (XI) and Agro Climatic Zone (NARP) Krishna - Godavari Zone (AP-1).

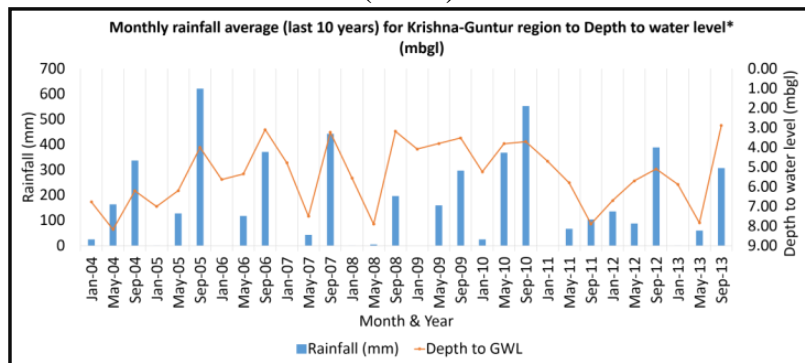

Fig 3 : Rainfall trend over the past Decade (2004-2013)

\section{Geological Characteristics:}

The Kondapalli hill range runs between Nandigama and Vijayawada cities in the district, for a length of $24 \mathrm{~km}$. Indrakiladri (Vijayawada), Mogalarajpuram and Jammalavoidurgam are other smaller hill ranges with a forest cover of 76186 hectares in the Krishna District while Guntur district comprises mainly of plains and the Nallamalai hill ranges in Palnad area. Krishna is the main river with many rivulets. The soil is mainly black cotton, red gravel, clay loamy, Sandy alluvial and red loam. Major minerals available in this district are: Limestone, Iron Ore, and Quartz, copper and clay.

The soils in general are very fertile and they are broadly classified as sandy loamy, Red loamy and Black cotton. Black cotton area is in $70 \%$, Red loamy in $24 \%$ and sandy loamy in about $6 \%$ of the area in the region.

The region has a distributed mineral resource, as seen below:

- $\quad$ Chromite-Kondapally hills and adjoining areas

- Diomond-Paritala, Ustepalls, Kodavatikallu,

Ramannapet, Kothapet, Suryavaram, Nemalipuram,

Mugaluru, Putrela etc.,

- $\quad$ IronOre-Jaggayapet

- LimeStone-Jaggayapet

- Mica-Tiruvuru

- Sulphur-Kona in Machilipatnam Mandal

- $\quad$ Copper and Lead:-Agnigundala of Ipur Mandal

Source:

\section{Rivers}

Krishna being great and sacred river of South Indian like Godavari and Kavery flows almost across the peninsula from West to East and finally joins the sea by two principal mouths. The perinial river Krishna flows across the region, covering both districts. The river covers parts of upland mandals as well as the delta mandals have the facility of utilizing the Krishna river water for irrigation purpose. The other streams and tributaries of the river that cover the region are Muniyeru, Budameru and Tammileru, Naguleru, Chandravanka and Gundlakamma. Muniyeru is the chief tributary of the river Krishna and it flows from North to South across erstwhile Jaggaihpeta and Nandigama taluks. This is an additional irrigation source available in this district. The Budameru hill stream which flows through several mandals viz., Mylavaram, G.Konduru, Mylavaram, Unguturu, Gannavaram, Gudivada, Mandavalli, Vijayawada, Kaikaluru and finally falls into Kolleru Lake. Agriculturally, the importance of the above sources is more as they do not only feed minor irrigation tanks but also provide for lift irrigation sources and ground water potential.

\section{E. Irrigation:}

The Major irrigation projects in the district are:

- $\quad$ Old Krishna Ayacut, now renamed as Prakasam

Barrage with an area of 202032 hectares and

DOI 10.17148/IARJSET.2015.2304 
- $\quad$ Nagarjuna Sagar Project with an area of 254583 hectares. Krishna river is the only source supporting both the Projects. Another alternate Irrigation channel by name (GBC) Guntur Branch Canal having an ayacutt of 10823 hectares and the Minor Irrigation water sources like filter points, tanks, tube wells etc., are providing reservoirs.

\section{F. Study Objectives:}

- $\quad$ To analyse the maps and delineate the possible lineaments in the vicinity of Vijayawada Guntur Tenali and Mangalagiri (VGTM) Region.

- To accentuate the potential natural resources which encircle the lineaments subject to the quality of hydrogeology by focusing the soil type, relief map, and drainage pattern.

\section{III.MeThODOLOGY}

\section{A. Data Anthology:}

Digital map are collected from Indian Society of Remote Sensing (Hyderabad Chapter), Vision 2025 - VGTM and Zonal Development Plan-2006. These are supported with supplementary data which are recently analysed based on SEISAT 2000 . The seismic data is collected. The classification of different type of soil.

\section{B. Data Establishment:}

The base maps are prepared by overlapping the data collected and analysed from Geological Survey of India (GSI) and Geographical Information System (GIS) Software. This data further leads to develop landscape thematic maps for Drainage pattern, vegetation pattern, Contour signature, Relief map and underground water storage potential. Additional lineaments coordinates are been imprinted over the base to ensure the zone of lineament in the vicinity of Vijayawada Guntur Tenali Mangalagiri (VGTM) to be appropriate.

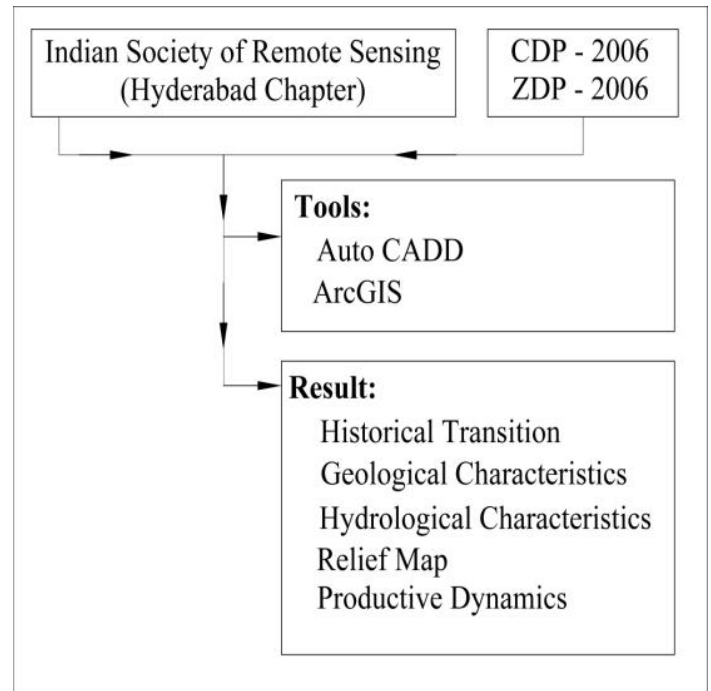

Fig 4: Methodology of zoning the lineament in the VGTM Region.

\section{IV.RESULTS AND DISCUSSIONS}

\section{A. Hydrological Characteristics:}

In one scenario where we have considered four different zones i.e., Zone 'A', Zone 'B', Zone 'C' and Zone 'D' which has been represented in Fig:5. In Zone 'A' i.e. Atchampet, Krosuru, Amravathi, Pedakurapadu and Sattenapalle we can find a rectangular drainage pattern which is used in the form of water canals to convey the urban drainage in the Krishna River. Similarly Zone 'B' i.e. Ibrahimpatnam, G.Konduru and Mylavaram is channelized as per Linear drainage pattern to convey in drainage Normal to the direction of the flow of Krishna river. In Zone ' $C$ ' i.e. Tadepalle, Mangalagiri, Pedadadani, Dugginala, Chebrolu, Vatticherukuru, Tenali, Tsundur and Amruthalur it is observed as Dendritic drainage pattern and in Zone ' $D$ ' i.e. the east side of VGTM region it is in the parallel drainage pattern in water canal.

The water canal map is overlapped over the relief map of $20 \mathrm{mts}$ contour interval and it is observed that the natural drainage pattern and the urban drainage pattern both resembles to orient water centric to Vijayawada Guntur Tenali and Mangalagiri (VGTM) Region.

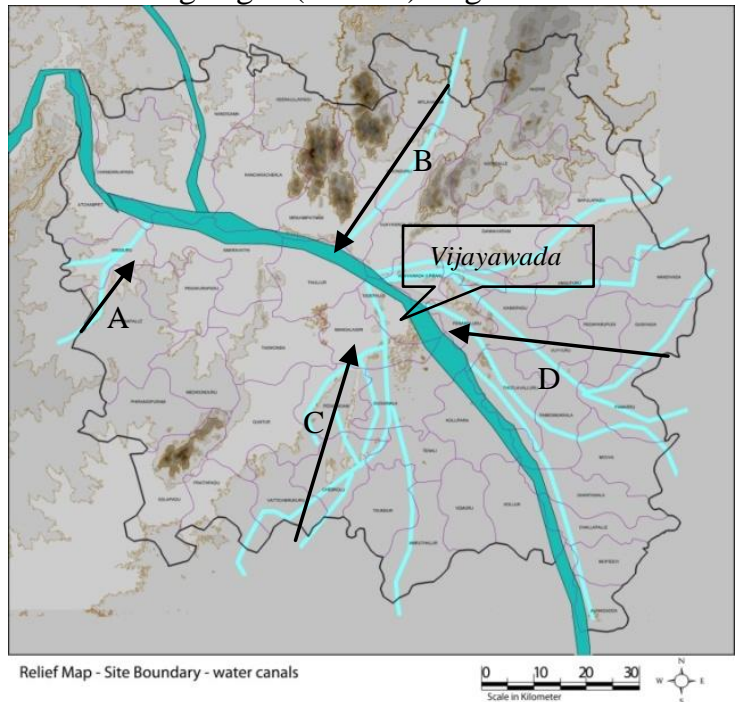

Fig 5 : Hydrological Characteristics along with existing water canals in VGTM region

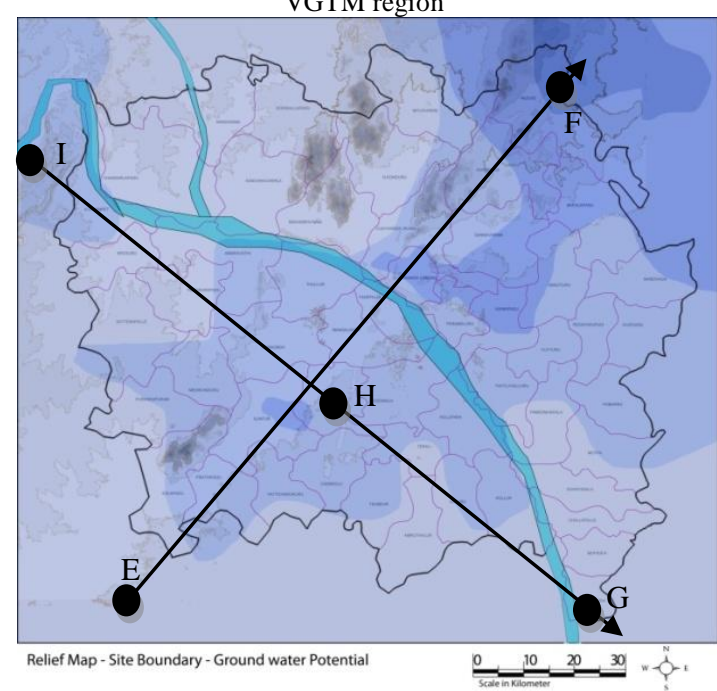

Fig 6 : Underground water potential along the Krishna River in VGTM region 
In an experiment of Log- Linear Analysis two linear axis The geology profile of this region clearly demarcates that are being considered and underground water level has the land profile is having a lineament in the Zone ' $\mathrm{M}$ ' as been contoured at an interval of $5 \mathrm{mts}$ in Fig: 6. The Axis represented in Fig: 8. The soil pattern is also stating that 'EF' results that the depth of water level is increasing from the Zone ' $\mathrm{M}$ ' is more fertile along with the highest $5 \mathrm{mts}$ at Point 'E' to more than $20 \mathrm{mts}$ depth at Point 'F'. underground water level recorded in this region, which The other Axis is along the flow of Krishna River i.e. represents a gradual change in water level along the axis 'IHG' where the intermediate point ' $\mathrm{H}$ ' is lower level when 'EF' as shown in Fig:6.

compared to 'I' and 'G'.

This represents that the Point 'I', Point 'E' and Point 'G' are having higher underground water depth where as Point ' $\mathrm{H}$ ' and Point ' $F$ ' represents the direction of increase in the level of water depth. This results that the water level variation is in linear format.

B. Projection of Topography as Relief Map:

The VGTM Region is majorly having two types of geography where most of the topography is having less gradient and is suitable for construction as per relief map and the other type where there are three zones recorded Zone ' $\mathrm{K}$ ', Zone 'L' and Zone ' $J$ '. The highest level recorded in this zone is $540 \mathrm{mts}$ level above the sea level which can be observed in the Zone ' $K$ ' represented in Fig: 7 and can also be termed as Kondapalli Hills. The Zone ' $J$ ' and Zone ' $L$ ' are both having the highest level of $480 \mathrm{mts}$ approximately.

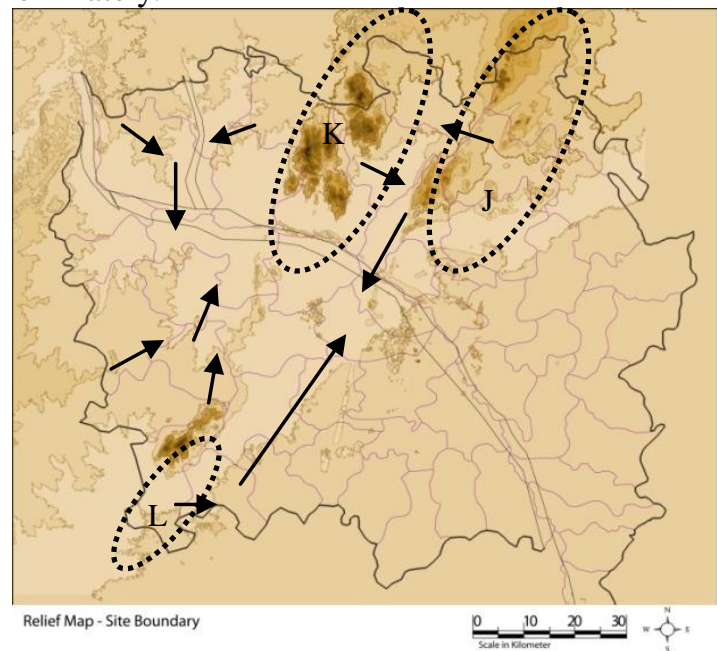

Fig 7 : Relief Map in VGTM region

A strong element of depression is observed in the middle of Zone ' $\mathrm{K}$ ' and Zone ' $\mathrm{J}$ ' representing a sturdy variation in the topography and soil pattern in linear format.

C. Productive Dynamics:

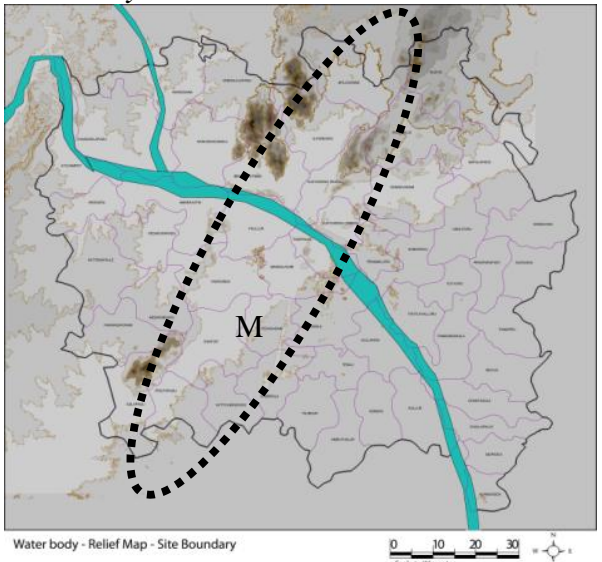

The Topography is that the lineament is perpendicular to the flow of Krishna river and is right through the centre of VGTM region facing the north east and south west direction. This increases the ability of the lineament to withhold the ground water for a longer period of time. This eventually ensures that the land is more productive in terms of ground water stability and the land fertility.

\section{Conclusion}

It becomes merely impossible to identify the lineament structure in the VGTM region by site visit, and even the conventional methods could take a lot of time, money and manpower. But its zones of lineament can always be identified and delineated by the other sources and the results could be much larger and vibrant in the field of ecology and environment.

It establishes a new study towards the sensitivity to the relation between the flora and water carrying capacity of the soil and its ability to maintain the natural underground drainage pattern. To a part this could also conclude that there is a high moisture holding capacity in these regions and there can be wetlands for a larger period of time when compared to other areas in the same region.

\section{REFERENCES}

[1] Ansal, A. (Jan-2004). Recent Advances in Earthquake Geotechnical Engineering and Microzonation. Netherlands: Kluwer academic Publisher.

[2] Babu, V. R. (Jan-2001). Plate Tectonic History of the Indian Plate Nellore-Khammam Schist Belt. Hyderabad: Indian Academy of Geoscience, Geology Department, Osmania University, 2001.

[3] D. W. O'Leary, J. D. (October, 1976). Lineament, linear, lineation: Some proposed new standards for old terms. Geological Society of America Bulletin , v. 87, no. 10, p. 1463-1469,.

[4] Department of Planning, (2009), Vijayawada Guntur Tenali Mangalagiri- 2025

[5] Hobbs, W. H. (1912). Earth features and their meaning. New York, The Macmillan Company, p. 506.

[6] Hobbs, W. H. (1904). Lineaments of the Atlantic Border region. the Geological Society of America, Vol. 15, p. 483-506.

[7] K. Nageswara Rao, P. S. (April 2012). Geomorphological implications of the basement structure in the Krishna-Godavari deltas, India. Zeitschrift für Geomorphologie , 40.

[8] Kanal, K. (1966). Observation of strong earthquake motions in Matsushiro. Business Environment Risk Intelligence, 44 (3).

[9] Novakowski, T. G. (March/April 2009). Identifying watershedscale barriers to groundwater flow: Lineaments in the Canadian Shield. Geological Society of America Bulletin , p. 333-347.

[10] Rahiman, T. I., \& Pettinga, J. R. (November 2008). Analysis of lineaments and their relationship to Neogene fracturing, SE Viti Levu, Fiji. Geological Society of America Bulletin, Vol. 120 Issue 11, p1544.

[11] Rai, K. P. (Sept 1997). Teleseismic delay-time tomography of the upper mantle beneath southeastern India: imprint of IndoAntarctica rifting. Geophysical Journal International

[12] Wallace Covington, P. K. (1998). Conference on Adaptive Ecosystem Restoration and Management. Fort Collins, Colorado 80523: DIANE Publishing.

Fig 8 : Lineament down the Krishna River in VGTM region 


\section{BIOGRAPHY}

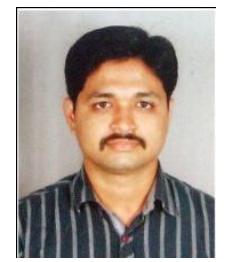

Kirthi Chandra was born in Hyderabad, India on 18th Dec, 1987. He has obtained his degree of B. Architecture (Landscape) from JNAFAU, Hyderabad and $M$. Landscape Architecture from SPA, New Delhi. Currently he is working as Assistant Professor at School of Planning and Architecture in Architecture Department. $\mathrm{He}$ is Registered Architect at COA and ISOLA member. He has been researching on Wetlands since 2010 in the form of Thesis and Dissertation. This research is majorly concentrates on identifying the potential of natural resource development which a geological structu re like lineament could deliver to the landscape of an newly developed urban fabric in VGTM Region.

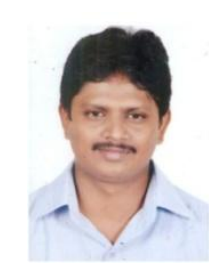

Mr Deen Maqbool Ahmed is currently working as Assistant Professor in Planning Department at School of Planning and Architecture Vijayawada. $\mathrm{He}$ has completed his post-graduate degree in Urban Planning (2008-10) from School of Planning and Architecture, New Delhi and B.Plan (2004-08) from School of Planning and Architecture, Hyderabad. His areas of interest includes urban environment, urban governance etc.

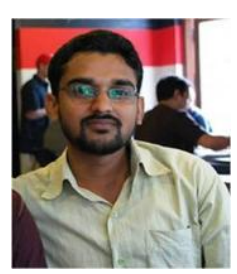

Mr G Sai Sanath is currently working as Assistant Professor in Architecture Department at School of Planning and Architecture Vijayawada. $\mathrm{He}$ has completed his post-graduate degree in Urban and Regional Planning from Institute of Development Studies, Mysore University and B.Arch (2004-08) from JNTU, Hyderabad. His areas of interest includes urban ecology, urban Planning etc. 